\title{
Interaction of 2'-deoxyguanosine with cis-2-butene-1,4-dial: Computational approach to analysis of multistep chemical reactions
}

\author{
L. K. Sviatenko ${ }^{1,2}$, L. G. Gorb ${ }^{1,3}$, D. M. Hovorun ${ }^{3}$, J. Leszczynski ${ }^{1}$ \\ ${ }^{1}$ Interdisciplinary Center for Nanotoxicity, Department of Chemistry and Biochemistry, Jackson State University \\ Jackson, Mississippi 39217, USA \\ ${ }^{2}$ Kirovohrad Volodymyr Vynnychenko State Pedagogical University \\ 1, Shevchenka Str., Kirovohrad, Ukraine, 25006 \\ ${ }^{3}$ State Key Laboratory of Molecular and Cellular Biology \\ Institute of Molecular Biology and Genetics, NAS of Ukraine \\ 150, Akademika Zabolotnoho Str., Kyiv, Ukraine, 03680 \\ jerzy@icnanotox.org
}

\begin{abstract}
cis-2-Butene-1,4-dial represents a microsomal metabolite of furan, an industrially important chemical found in cigarette smoke, air pollution, and also in canned or jarred food. It is expected to be a human carcinogen. Aim. Investigation of an effect of cis-2-butene-1,4-dial on the 2'-deoxyguanosine which is a model of DNA site. Methods. Optimization of reaction species molecular structures, spectral parameters and Gibbs free energy calculations were performed using Gaussian09 program. Systems of differential equations for kinetics generation were solved using Mathcad15 program. Results. The predicted mechanism of the reaction of cis-2-butene-1,4dial with 2'-deoxyguanosine consists of four-step process formation of four diastereomeric primary adducts and further base-mediated five-step transformation of the primary adducts to the secondary one. The reaction kinetics, which allows defining the concentration change of any reaction species was calculated. Conclusions. Under physiological conditions the interaction between cis-2-butene-1,4-dial and 2'-deoxyguanosine leads to the formation of a stable adduct which could be responsible for the furan genotoxicity.
\end{abstract}

Keywords: furan, DNA, DFT, mechanism, kinetics.

Introduction. Furan is widely used in industry. It is an important environmental compound found in food, cigarette smoke, and air pollution [1,2]. In organism it undergoes oxidation by cytochrome P450 forming cis2-butene-1,4-dial (BDA), which mediates the furan toxic effects [3].

The mechanism of furan carcinogenesis is not wellunderstood. BDA has been shown to induce the DNA single-strand breaks and cross-links in cells [4]. Investigations of DNA adducts can provide insight into the mechanisms of carcinogenesis and toxicity. The experimental studies have shown that the microsomal metabolite of furan, BDA, reacts with $\mathrm{dCyd}$ to form an oxadi-

(C) Institute of Molecular Biology and Genetics, NAS of Ukraine, 2014 azabicyclooctaimine adduct and with dAdo and dGuo that initially forms ethano adducts. Those adducts are rearranged, which leads to the formation of ethenoacetaldehyde adducts [5-7].

Our previous studies have shed light on the mechanism of formation of dAdo-BDA adducts [8]. The current study describes the mechanism and kinetics of interaction of BDA with dGuo. The experimental studies have shown that the products of the BDA initial reaction are relatively unstable with a half-life smaller than $4 \mathrm{~h}$ and decompose to multiple unidentified compounds $[6,7]$. There are two possible pathways that could result from the reaction of BDA at both the N1 and N2 positions of dGuo (Scheme). Spectral analysis allows identifying the major primary and secondary reaction 


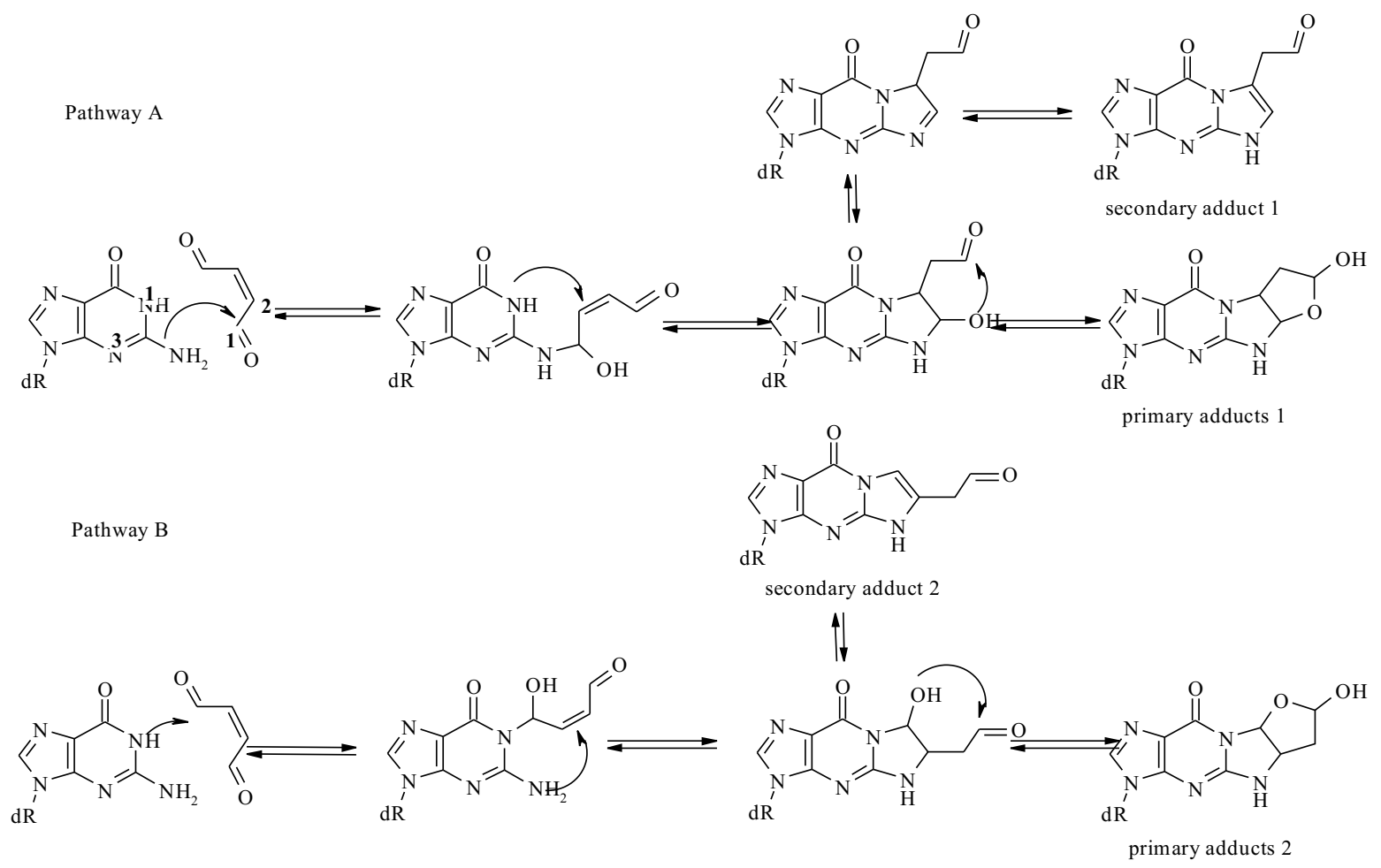

products, which are diastereomeric hemiacetal forms of 3-(2'-deoxy- $\beta$-D-erythropentafuranosyl)-3,5,6,7-tetrahydro-6-hydroxy-7-(ethane-2"-al)-9H-imidazo[1,2$\alpha$ ]purine-9-one and 3-(2'-deoxy- $\beta$-D-erythropentafuranosyl)imidazo-7-(ethane-2"-al) $[1,2-\alpha]$ purine-9-one, respectively $[6,7]$. These structures correspond to the pathway A. A proposed reaction mechanism involves an initial nucleophilic attack of exocyclic nitrogen atom $\mathrm{N}_{2}$ of dGuo on the $\mathrm{C}_{1}$ atom of BDA. Then 1,4-addition of the adjacent endocyclic nitrogen atom $\mathrm{N}_{1}$ of dGuo to the double bond of the remaining $\alpha, \beta$-unsaturated aldehyde occurs.

The final step represents a subsequent attack of the hydroxyl group on the second aldehyde group to form the primary dGuo-BDA adducts. Further, these adducts undergo transformation to the secondary product by the dehydration reaction.

The aim of the present work is the investigation of the mechanism, thermodynamics and kinetics of the primary and secondary dGuo-BDA adducts formation.

Materials and methods. All the calculations were performed using the Gaussian09 program package [9]. The relevant stationary points (reagents, intermediates, transition states, and products) were fully optimized at the M05-2X/6-311+G(d) level [10]. A water molecule was used as a catalyst when it was necessary. Singlepoint calculations in aqueous solution were carried out at the gas-phase-optimized geometry for the adducts and corresponding transition states using PCM at the M06-2X/6-311++G(d,p) level of theory. The relevant stationary points (reagents, intermediates, transition states, and products) were fully optimized at the PCM/M06$2 \mathrm{X} / 6-311++\mathrm{G}(\mathrm{d}, \mathrm{p})$ level in case of base-catalyzed mechanism.

All stationary points were further characterized as minima with all real frequencies, or as transition states with the only one imaginary frequency, by computations of analytic harmonic vibrational frequencies at the same theory level as geometry optimization.

UV-Vis spectra of dGuo and dGuo-BDA adducts were simulated at the PCM/M05-2X/6-311+G(d) level. NMR spectra of products were calculated applying M06$2 \mathrm{X}$ method that uses gauge independent atomic orbitals (GIAO) NMR computational formalism and PCM solvation model.

Uni- and bi-molecular rate constants were calculated according to the equations:

$$
k_{u n i}=\frac{k \cdot T}{h} \cdot e^{-\frac{\Delta G_{T}^{ \pm}}{R T}}\left(\mathrm{~s}^{-1}\right) ;
$$




$$
k_{b i}=\frac{k \cdot T}{h} \cdot e^{-\frac{\Delta G_{T}^{ \pm}}{R T}} \cdot\left(\frac{1}{c}\right)\left(\mathrm{L} \cdot \mathrm{mol}^{-1} \cdot \mathrm{s}^{-1}\right),
$$

where $k$ is the Boltzmann constant; $T$ - temperature; $h-$ Planck constant; $\Delta G_{T}^{\#}-$ Gibbs free energy; $R$ - universal gas constant; $c$ - transformation coefficient equal to one $\mathrm{mol} \cdot \mathrm{L}^{-1}$.

The rate constants $k_{u n i}$ and $k_{b i}$ calculated using the equations (1) and (2) were applied to predict the rate of reagents' decay and the rate of accumulation of products and intermediates that are presented in the Scheme. For this purpose the system of differential equations having the following general form described below (the real form of differential equations is presented in Supporting Information) has been solved.

$$
\begin{gathered}
\sum_{i} \frac{d n_{i}}{d t}=\sum_{\substack{j \\
(j \neq i)}} k_{j i} n_{j}-n_{i} \sum_{\substack{l \\
(j \neq i)}} k_{i l}, \\
\sum_{i} \frac{d n_{i}}{d t}=\sum_{\substack{j \\
(j, m \neq i)}} k_{j i} n_{j} n_{m}-n_{i} \sum_{\substack{l \\
(j, o \neq i)}} k_{i l} n_{o} .
\end{gathered}
$$

The systems of kinetic equations (3) were solved by using a Mathcad 15 program. The initial concentrations of dGuo and BDA (corresponding to experimental data) are equal to $5 \mathrm{mmol} / \mathrm{L}$ and $25 \mathrm{mmol} / \mathrm{L}$, respectively, and the temperature is $37^{\circ} \mathrm{C}$.

Results and discussion. At the beginning of our study we have calculated UV-Vis and NMR spectra of dGuo adducts of BDA and compared them with the available experimental data to verify the structure of products. The calculated and experimental spectra are similar, that supports the structures of the products which were proposed by experimentalists. It should be noted that the UV-Vis spectra of primary products are identical, indicating that these products are isomers. They display an absorption maximum at $223 \mathrm{~nm}$ and a slight shoulder at $237 \mathrm{~nm}$ (exp. 250.9 and $275 \mathrm{~nm}$ ) (Fig. S1, SI). The major product of their decomposition has a UV-Vis spectrum with $\lambda_{\text {max }}$ at 208 and $240 \mathrm{~nm}$ (exp. 229 and $284 \mathrm{~nm}$ ) (Fig. S1, SI). The calculated ${ }^{13} \mathrm{C}$ and ${ }^{1} \mathrm{H}$ chemical shifts for primary dGuo adducts of cis-2butene-1,4-dial in DMSO are also in good correspondence with the experimental NMR spectra (Tables S1, S2). The structural characterization of the secondary product by ${ }^{1} \mathrm{H}$ NMR was complicated due to its instability. To circumvent this problem, methoxyamine deriva- tives of secondary dGuo-BDA adduct were synthesized and their spectra were obtained (Scheme S1). These spectra are in a good correspondence with our calculated results (Table S3).

Reaction mechanism of the primary 2'-deoxyguanosine adducts of cis-2-butene-1,4-dial formation. At the first step of the reaction the exocyclic atom $\mathrm{N}_{2}$ of dGuo attacks the carbonyl $\mathrm{C}_{1}$ atom of BDA. As a result two stereoisomeric intermediates (INT1 and INT2) arise (Fig. 1). The Gibbs free energies for this step are about $33 \mathrm{kcal} / \mathrm{mol}$. The formed intermediates are characterized by similar stability and are slightly more stable than reagents.

Next step of the reaction is a lactam-lactim tautomerization of intermediates INT1 and INT2 into their tautomers INT3 and INT4 (Fig. 1). It occurs rapidly and needs only about $15 \mathrm{kcal} / \mathrm{mol}$ Gibbs free activation energy. This isomerisation facilitates further five-membered cycle formation. The cycle closure in intermediates INT3 and INT4 leads to stable stereomeric intermediates INT5-INT8, which are more than $12 \mathrm{kcal} / \mathrm{mol} \mathrm{stab}-$ ler than their corresponding ring-opened forms (Fig. 1). The activation free energy barrier for these processes is $21-25 \mathrm{kcal} / \mathrm{mol}$.

The intermediates INT6 and INT8 have functional groups which are situated close together that provide facilities for further cyclization. While INT6 and INT13 intermediates do not undergo cyclization because of steric separation of these functional groups. Furan cycle closing in intermediates INT6 and INT8 results in the formation of products PR11 and PR12, and products PR13 and PR14, respectively (Fig. 2). These four diastereomeric products are reported as primary dGuoBDA adducts, have the same stability and differ by orientation of five-membered furan cycle and hydroxyl group. The Gibbs free energy activation barriers for these pathways are $22.20-27.41 \mathrm{kcal} / \mathrm{mol}$.

The intermediates INT5-INT8 may be transformed to the secondary dGuo-BDA product PR 15 by two-step pathway. The first step is a dehydration which leads to isomeric intermediates INT9 and INT10. The second one is amine imine isomerization. Both these processes have Gibbs free activation energy in a range of 31-36 $\mathrm{kcal} / \mathrm{mol}$.

Summarizing calculated results, the general profile of the change of Gibbs free energy along the reaction 

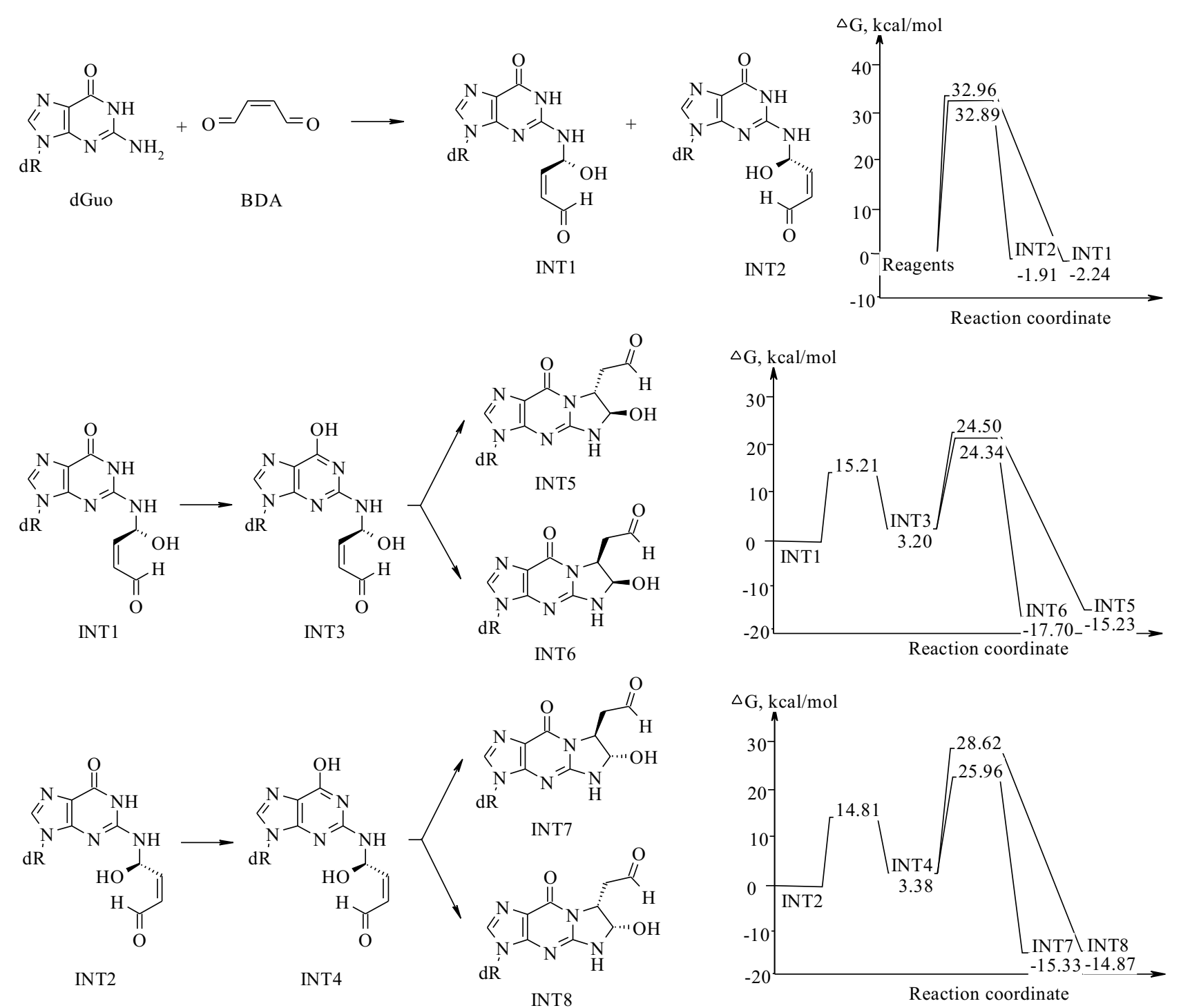

Fig. 1. PCM/M06-2X/6-311++G(d,p)//M05-2X/6-311+G(d) level computer generated initial pathways of 2'-deoxyguanosine reaction with cis2-butene-1,4-dial, corresponding Gibbs free energy diagram

coordinate that starts from the reactants and ends at the products is presented in Fig. S3. The first step of the reaction is rate-limiting for the primary products formation. On the basis of the obtained results, one may conclude that the primary adducts are formed faster than the secondary product, however, the latter is more stable than the primary ones. That supports the experimental data according to which at the beginning of the reaction the primary products are detected. While the secondary dGuo product was also isolated from the reaction mixtures of dGuo and BDA incubated for $24 \mathrm{~h}$ at $37^{\circ} \mathrm{C}$.

To describe kinetics of the whole processes shown in the Figs 1-2 the values of Gibbs free energy barriers (with application of a single scaling factor which results in $29 \%$ decreasing of all energies) have been converted to the set of rate constants. Such rate constants are presented in Supporting Information in the Table S3 along with the kinetic equations (Scheme S1) which describe the chemical process displayed in Figs 1-2. Such approach has been successfully used in our previous kinetic study of dAdo-BDA adducts formation. Kinetic plots allow analysis the reaction course with time. The observed and computationally predicted kinetics are shown in Fig. 3. As one can see the decrease in dGuo levels is greater than the increase in adduct levels. This is explained by the multiple products formation under the reac- 


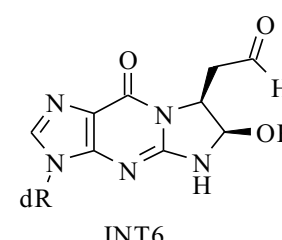<smiles>Cn1cnc2c(=O)n3c(nc21)N[C@@H](O)C3CC=O</smiles>
$\mathrm{dR}$

INT7<smiles>O=CCC1Cn2c(nc3cn[nH]c3c2=O)NC1O</smiles>

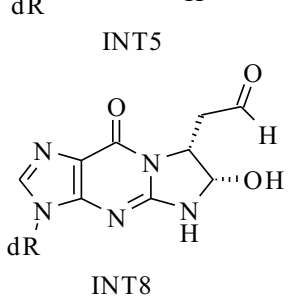

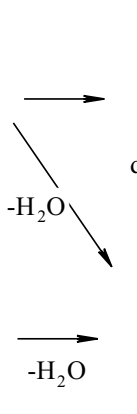<smiles></smiles>

PR11<smiles>CC=CCC1C=Nc2nc3c(ncn3[AlH2])c(=O)n21</smiles>

INT9<smiles>[13CH3]n1cnc2c(=O)n3c(nc21)NC1OC(O)CC13</smiles>

PR 12<smiles>O=CCc1c[nH]c2nc3c(ncn3[Tl])c(=O)n12</smiles>

PR 15
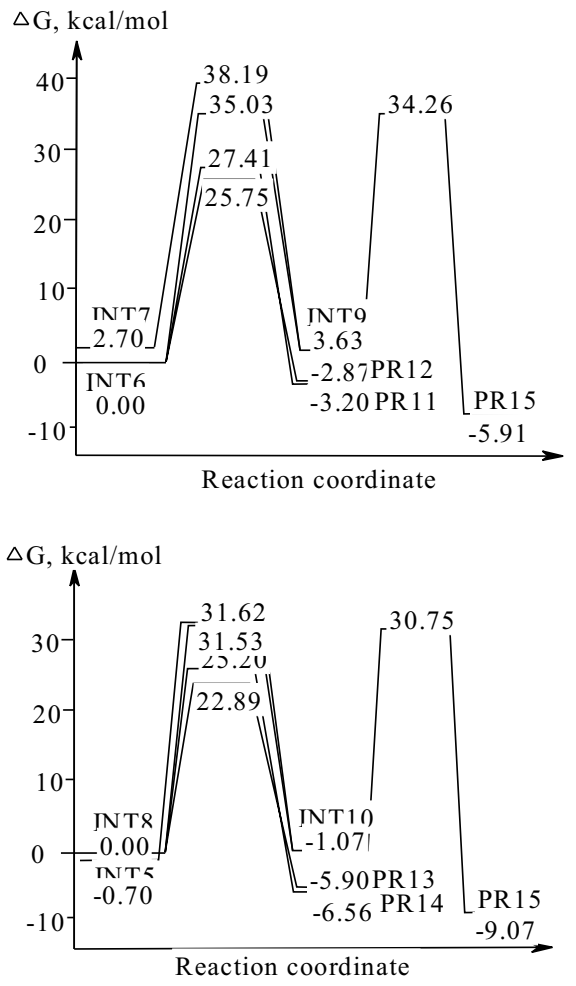

Fig. 2. PCM/M06-2X/6-311++G(d,p)//M05-2X/6-311+G(d) level computer generated pathways of INT5-INT8 transformations, corresponding Gibbs free energy diagrams

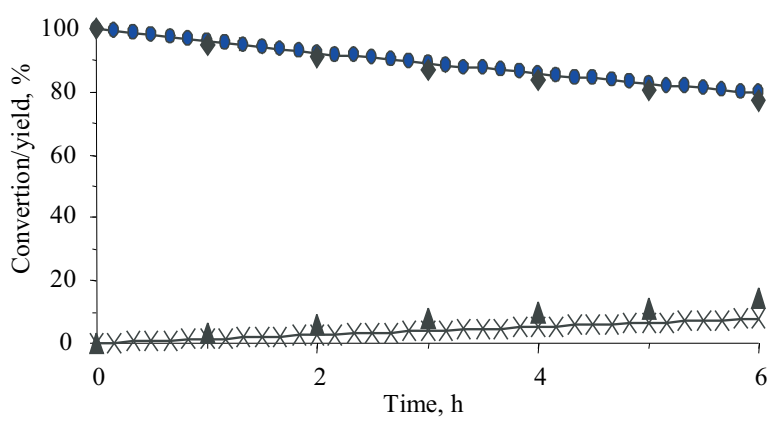

Fig. 3. Kinetic plot of the primary dGuo adducts of cis-2-butene-1,4dial (PR11-PR14) formation reaction calculated at $37^{\circ} \mathrm{C}$ at the PCM/ M06-2X/6-311++G(d,p)//M05-2X/6-311+G(d) level; • - dGuo (calc.); - dGuo (exp.); $\boldsymbol{X}$ - PR11-PR14 (calc.); $\boldsymbol{\Delta}$ - primary adducts (exp.)

tion conditions. The calculated results show a good agreement with the experimental data for the dGuo transformation while they predict slower increase of the primary products concentration than the measured one. That arises perhaps due to underestimation of the stability of primary products compare to those of intermediates (see Fig. 2).

The analysis of kinetic plot allows us to determine a relative amount of each isomer in the mixture. Accor- ding to HPLC analyses the reaction generated two new closely eluting peaks. NMR analysis of each peak indicated that each one contained two co-eluting isomers at a ratio of 1:2. As can be seen from Fig. S4 the major isomers in each pair are PR11 and PR14. Our calculations also support the formation of significant amount of the secondary product after $24 \mathrm{~h}$ of reaction proceeding (see Fig. S5).

Reaction mechanism of primary $\rightarrow$ secondary diastereomeric adducts transformation. It is also interesting to consider the conversion of primary dGuo-BDA adducts to secondary one since we have the experimental data related to their half life, which amount to 2.2 and $3.4 \mathrm{~h}$ for two pair of isomers. We have found that the transformation may occur in three steps. The proton transfer from nitrogen to oxygen atom in primary products (PR11-PR14) is accompanied by furan cycle opening and results in the intermediates INT16 and INT17 formation (Fig. 4). The dehydration of these intermediates leads to intermediates INT9 and INT10, which isomerize to product PR15. It should be mention that primary products may be converted to secondary one 


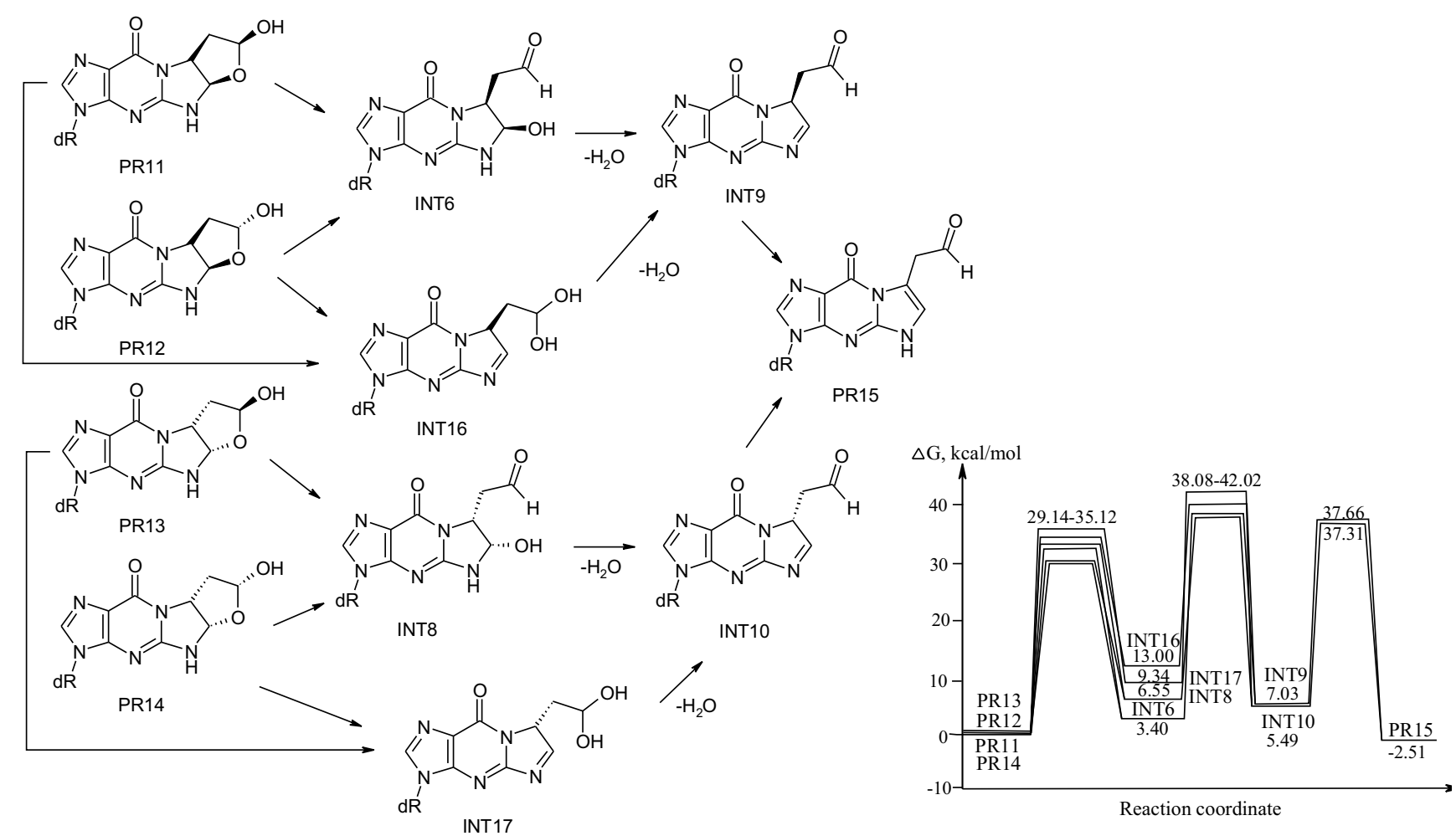

Fig. 4. PCM/M06-2X/6-311++G(d,p)//M05-2X/6-311+G(d) level computer generated pathways of primary $\rightarrow$ secondary products transformation, corresponding Gibbs free energy diagram

through their ring-opened forms (INT6 and INT8). However, a thorough analysis of the corresponding Gibbs free energy diagram evidences that these pathways are hard to realize due to the high free activation barriers (Fig. 4). Since half-lives of the primary adducts lengthened with decreasing $\mathrm{pH}$, we have studied a basecatalyzed mechanism for their transformation.

The base-mediated decomposition of primary products consists of five steps. The proton abstraction from nitrogen atom by hydroxide ions leads to intermediates INT18-INT21 (Fig. 5). Further transformation of these intermediates passes through furan ring opening and results in the formation of intermediates INT22-INT25, which isomerize to intermediate INT26 by the intermolecular proton transfer. The dehydration of intermediate INT26 leads to intermediate INT27 which converts to the secondary product PR 15 by the proton attaching to a nitrogen atom. The rate limiting step for the process is dehydration with free activation barrier of $26.35 \mathrm{kcal} /$ mol. Base-catalyzed dehydration appears to be more realistic compared to water-catalyzed mechanism, that is in agreement with the experimental data [7]. The kinetics of the base-catalyzed dehydration has been calculated using a single scaling factor for reducing the Gibbs free energy barriers by $17 \%$. The computationally predicted kinetic plots of products and intermediates are shown in Fig. 6 and Fig. S6 (as Supporting Information), respectively. As can be seen from the Fig.6 the calculated half lives of the primary adducts are in good agreement with the experimental values.

Conclusions. The mechanism of interaction of dGuo with BDA has been proposed based on the computational studies. The suggested reaction pathways along with the simulated UV-Vis and NMR spectra indicate that the primary and secondary dGuo reaction products present hemiacetal forms of 3-(2'-deoxy- $\beta$-D-erthyropentafuranosyl)-3,5,6,7-tetrahydro-6-hydroxy-7-(ethane-2"al)-9H-imidazo[1,2- $\alpha$ ]purine-9-one (PR11-PR14) and 3- (2'-deoxy- $\beta$-D-erythropentafuranosyl)imidazo-7-(ethane-2"-al) $[1,2-\alpha]$ purine-9-one (PR15), respectively, which is in agreement with the experimental results. The primary products formation is a four-step process with an initial attack as a rate-limiting step. The process passes through the initial reaction of the exocyclic nitrogen N2 atom of dGuo with the $\mathrm{C}_{1}$ atom of BDA, further cyclization by addition of the adjacent endocyclic nitrogen 

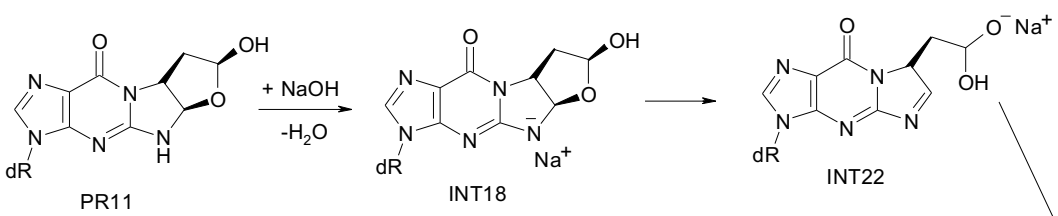

(NR

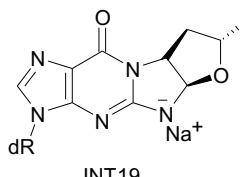<smiles>[R7]n1c(C)nc2c(=O)n3c(nc21)N=C[C@H]3CC([NH3+])O</smiles><smiles>[R]n1cnc2c(=O)n3c(nc21)N[C@@H]1O[C@H](O)C[C@@H]13</smiles><smiles>[R]n1cnc2c(=O)n3c(nc21)[NH2+][C@@H]1O[C@H](O)C[C@H]13</smiles><smiles>[R1]OC(O)C[C@@H]1C=Nc2nc3c(ncn3[R1])c(=O)n21</smiles><smiles></smiles><smiles></smiles>

dR PR13

INT20<smiles>[R12][R]([R1])n1cnc2c(=O)n3c(nc21)N[C@H]1O[C@H](O)C[C@H]13</smiles><smiles>[R7]n1cnc2c(=O)n3c(nc21)[C@@H]1C[C@H](O)O[C@H]1[NH+]3[NH3+]</smiles><smiles>OCCO</smiles>

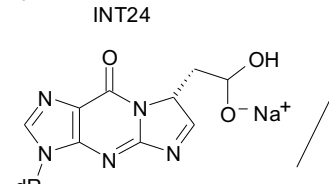
$\mathrm{dR}$ INT25

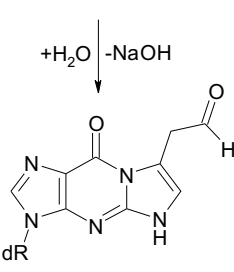

PR15

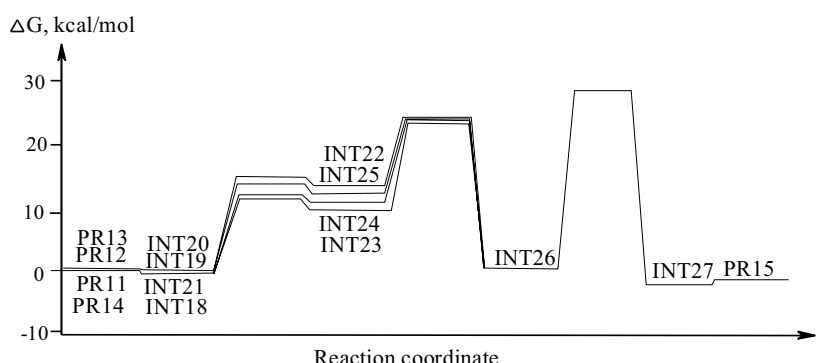

Fig. 5. PCM/M06-2X/6-311++G(d,p) level computer generated pathways of base-catalyzed primary $\rightarrow$ secondary adducts transformation, corresponding Gibbs free energy diagram

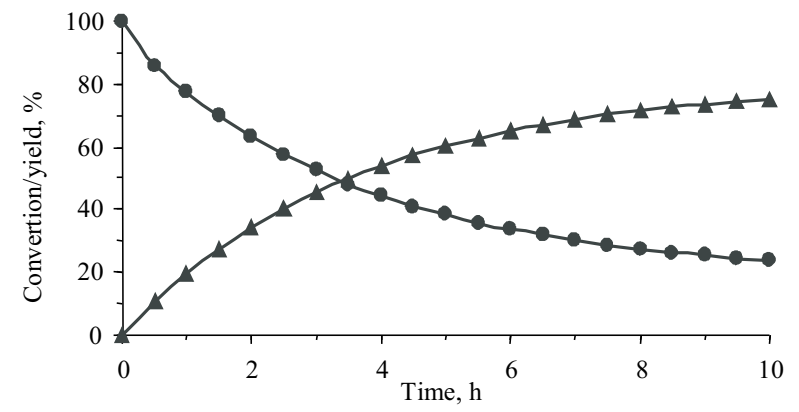

Fig. 6. Kinetic plot for the primary $\rightarrow$ secondary dGuo adducts of cis2-butene-1,4-dial transformation reaction calculated at $37^{\circ} \mathrm{C}$ at the PCM/M06-2X/6-311++G(d,p) level; • - PR11-PR14 (calc.); PR15

atom $\mathrm{N}_{3}$ of dGuo to the double bond of the remaining $\alpha$, $\beta$-unsaturated aldehyde, and final cyclization by an attack of the hydroxyl on the second aldehyde group. Replacement of the last step by two other steps (dehydration and isomerization) results in formation of the secon- dary product (PR15). Base-mediated five-step transformation of the primary adducts to the secondary one involves proton abstraction by hydroxide ion, furan ring opening, isomerization, water abstraction and proton attachment. Kinetic plots for these processes have been obtained by construction and solving the corresponding kinetic equations. The calculated mechanism of formation of primary dGuo-BDA adducts is similar to one for interaction of dAdo with BDA. While transformation of primary products to a secondary one needs a base catalyst for dGuo-BDA adducts and passes through an acidcatalyzed process in case of dAdo-BDA products. The obtained results are in good agreement with the experimental data and demonstrate that under mild, biological conditions BDA reacts with dGuo to form multiple products which could be responsible for furan mutagenesis.

Funding. This work was supported by the CREST (grant N HRD-0833178); the Extreme Science and En- 
gineering Discovery Environment (XSEDE) by National Science Foundation (grant N OCI-1053575); the XSEDE award allocation (N DMR110088); and the Mississippi Center for Supercomputer Research.

Взаємодія 2'-дезоксигуанозину з циис-2-бутен-1,4-діалем: обчислювальний підхід до аналізу багатоступеневих хімічних реакцій

\section{Л. К. Святенко, Л. Г. Горб, Д. М. Говорун, Є. Лещинський}

\section{Резюме}

цис-2-Бутен-1,4-діаль є мікросомним метаболітом фурану-промислово важливого хімікату, виявленого в сигаретному димі, забрудненому повітрі, а також, іноді, в консервованих або банкових продуктах. Його вважають потениійним канцерогеном для людини. Мета. Дослідити вплив иис-2-бутен-1,4-діалю на 2'-дезоксигуанозин - модельний фрагмент ДНК. Методи. Оптимізаиію структури учасників реакиії, розрахунки спектральних параметрів і вільної енергії Гіббса виконано в програмі Gaussian09. Системи диференційних рівнянь для отримання кінетичних даних вирішували з використанням програми Mathcad15. Результати. Прогнозований механізм реакції ичис-2-бутен-1,4-діалю з 2'-дезоксигуанозином реалізується у чотири стадіï, протягом яких утворюються чотири діастереоізомерних первинних адукти, з наступною n'ятистадійною трансформачією, каталізованою основами, первинних адуктів у вторинні. Розраховано кінетику реакції, щзо дозволяє визначати зміни концентрації будь-якого учасника реакиії. Висновки. За фізіологічних умов взаємодія між ичи-2-бутен-1,4-діалем і 2'-дезоксигуанозином призводить до утворення стабільного адукта, який може відповідати за генотоксичність фурану.

Ключові слова: фуран, ДНК, ДФТ, механізм, кінетика.

Взаимодействие 2'-дезоксигуанозина с цис-2-бутен-1,4-диалем: вычислительный подход к анализу многоступенчатых химических реакций

Л. К. Святенко, Л. Г. Горб, Д. Н. Говорун, Е. Лещинский

\section{Резюме}

цис-2-Бутен-1,4-диаль является микросомным метаболитом фурана - промышленно важного химиката, обнаруженного в сига ретном дыме, загрязненном воздухе, а также, иногда, в консервированных или баночных продуктах. Его считают потенциальным каниерогеном для человека. Цель. Исследовать влияние иис2- бутен-1,4-диаля на 2'-дезоксигуанозин-модельный фрагмент ДНК. Методы. Оптимизацию структуры участников реакции, расчеты спектральных параметров и свободной энергии Гиббса выполняли в программе Gaussian09. Системы дифференциальных уравнений для получения кинетических данных решали с помощью программы Mathcad15. Результаты. Реакция ичис-2-бутен-1,4диаля с 2'-дезоксигуанозином проходит в четьре стадии с формированием четырех диастереоизомерных первичных аддуктов и последующей, катализируемой основаниями, пятистадийной трансформачией первичных аддуктов во вторичные. Рассчитана кинетика реакиии, что позволяет определять изменения кониентрации любого участника реакиии. Выводы. При физиологических условиях взаимодействие между иис-2-бутен-1,4-диалем и 2'- дезоксигуанозином приводит к образованию стабильного аддукта, который может отвечать за генотоксичность фурана.

Ключевые слова: фуран, ДНК, ДФТ, механизм, кинетика.

\section{REFERENCES}

1. U.S. Department of Health and Human Services. Public Health Service. National Toxicology Program. Report on carcinogens. Twelfth Edition. Washington, DC, 2011; 499 p.

2. Exploratory Data on Furan in Food: Individual Food Products. U. S. Food and Drug Administration, 2008.

3. Chen LJ, Hecht SS, Peterson L. Identification of cis-2-butene1,4-dial as a microsomal metabolite of furan. Chem Res Toxicol. 1995; 8(7):903-6.

4. Marinari UM, Ferro M, Sciaba L, Finollo R, Bassi AM, Brambilla $G$. DNA-damaging activity of biotic and xenobiotic aldehydes in Chinese hamster ovary cells. Cell Biochem Funct. 1984; 2(4):243-8.

5. Gingipalli L, Dedon PC. Reaction of cis- and trans-2-Butene-1,4dial with 2'-deoxycytidine to form stable oxadiazabicyclooctaimine adducts. J Am Chem Soc. 2001;123(11):2664-5.

6. Byrns MC, Predecki DP, Peterson LA. Characterization of nucleoside adducts of cis-2-butene-1,4-dial, a reactive metabolite of furan. Chem Res Toxicol. 2002;15(3):373-9.

7. Byrns $M C, V u C C$, Peterson LA. The formation of substituted 1 , N6-etheno-2'-deoxyadenosine and 1,N2-etheno-2'-deoxyguanosine adducts by cis-2-butene-1,4-dial, a reactive metabolite of furan. Chem Res Toxicol. 2004;17(12):1607-13.

8. Sviatenko L, Gorb L, Hovorun D, Leszczynski J. Interaction of 2'deoxyadenosine with cis-2-butene-1,4-dial: computational approach to analysis of multistep chemical reactions. J Phys Chem A. 2012;116(9):2333-42.

9. Frisch MJ, Trucks GW, Schlegel HB, Scuseria GE, Robb MA, Cheeseman JR, et al. Gaussian 09, Revision A.01, Gaussian Inc., Wallingford, CT, 2009.

10. Zhao $Y$, Truhlar DG. Density functionals with broad applicability in chemistry. Acc Chem Res. 2008; 41(2):157-67.

Received 10.02.14 